\title{
(Mis)Understanding Political Participation
}

Digital Practices, New Forms of Participation and the Renewal of Democracy

Edited by Jeffrey Wimmer, Cornelia Wallner, Rainer Winter and Karoline Oelsner 


\section{Contents}

Introduction

JEFFREY WIMMER, CORNELIA WALLNER, RAINER WINTER AND KAROLINE OELSNER

\section{PART I}

Practices of Participation and Citizenship

1 (New) Forms of Digital Participation? Toward a Resource Model of Adolescents' Digital Engagement

ANNIKA SCHREITER, SVEN JÖCKEL AND KLAUS KAMPS

2 Long-Lasting Shadows of (Post)Communism? Generational and Ethnic Divides in Political and Civic Participation in Estonia

VERONIKA KALMUS, RAGNE KÕUTS-KLEMM, MAI

BEILMANN, ANDU RÄMMER AND SIGNE OPERMANN

3 Enhanced Inter-visibility. The Experience of Civic Engagement in Social Media

MARIA FRANCESCA MURRU

4 'I Am Not a Consumer Person' - Political Participation in

Repair Cafés

SIGRID KANNENGIEßER

5 Intimate Citizenship Politics and Digital Media: Teens'

Discourses, Sexual Normativities and Popular Social Media

SANDER DE RIDDER AND SOFIE VAN BAUWEL

\section{PART II}

Mediated Representations of Participation and Citizenship 109

6 The Indignados in the European Press: Beyond the 
vi Contents

7 Speak Your Mind: Mediatised Political Participation Through Second Screens

UDO GÖTTLICH AND MARTIN R. HERBERS

8 "My Body, My Decision". The Abortion Debate and Twitter as a Counterpublic Sphere for Women in Turkey

PERRIN ÖGUUN EMRE AND GULUUM ȘENER

9 Repeat, Remediate, Resist? Digital Meme Activism in the Context of the Refugee Crisis

ELENA PILIPETS AND RAINER WINTER

PART III

(Re-)Framing Participation and Citizenship

10 Towards a Framework for Studying Political

Participation in Social Media

JULIE ULDAM AND ANNE KAUN

11 Protest or Collaboration? How Perceived Opportunities and Constraints Shape the Activities of Anti-Infrastructure Citizen Action Groups

MARCO BRÄUER AND JENS WOLLING

12 Visibility, Voice and Encounter in Cosmopolitan Online Communication. Rethinking Cultural Citizenship in Post-Migrant Societies

ELKE GRITTMANN AND TANJA THOMAS

13 Mapping the 'Search Agenda': A Citizen-Centric Approach to Electoral Information Flows

FILIPPO TREVISAN, ANDREW HOSKINS, SARAH OATES

AND DOUNIA MAHLOULY

List of Contributors

Index 